\title{
GAMBARAN INDUKSI ELEKTROMAGNETIK BEBERAPA JENIS HANDPHONE YANG DIGUNAKAN MAHASISWA KEDOKTERAN ANGKATAN 2013
}

\author{
${ }^{1}$ Rich V Wowor \\ ${ }^{2}$ Jimmy F. Rumampuk \\ ${ }^{2}$ Fransiska. Lintong
}

\author{
${ }^{1}$ Kandidat Skripsi Fakultas Kedokteran Universitas Sam Ratulangi Manado \\ ${ }^{2}$ Bagian Fisika Fakultas Kedokteran Universitas Sam Ratulangi Manado \\ Email: rich_wowor@yahoo.co.id
}

\begin{abstract}
Mobile phone is a source of potentially harmful radiation. The form of signals in two radiation field, the near magnetic field and the remote magnetic field. This research is quantitative, with a cross-sectional approach. The results of the study, the highest standby electromagnetic waves is BlackBerry smartphone, while lowest one is the Samsung. At the calling modes, highest is Blackberry and Nokia and the lowest one is Samsung. At the receiving modes the biggest wave is Blackberry, lowest is Samsung. Based on the results of the ANOVA test it was found that there is a significant difference $(\mathrm{p}=0.003, \mathrm{p}<0.05)$ in the fourth electromagnetic waves smartphone brands when making a call. While in standby and receive calls no significant difference $(p=0.120$ and $p=0.115, p>0.05)$. Therefore, no difference statistically and required further analysis (post-hoc) to test the Least Significant Difference (LSD) or the Least Significance difference (LSD). There is a significant difference between the top of the electromagnetic wave smartphone brands Samsung, Nokia, and Blackberry at the time of call. While all four brands of smartphones is apparently the difference electromagnetic waves of the Samsung and Nokia with significant difference $(p=0.001)$, followed by the differences between the Samsung and Blackberry $(p=0.002)$. It can also take a look at the difference in the mean difference of the four brands of electromagnetic waves where the average difference between Nokia and Samsung is the smallest (-4.035), followed by the difference between the Samsung with Blackberry (-4.001).
\end{abstract}

Keywords: handphone, electromagnetic wave, radiation field.

Abstrak: Handphone merupakan sumber radiasi potensial yang membahayakan. Signal telepon seluler yang dikirim membentuk dua buah lapangan radiasi yakni, medan magnet dekat dan medan magnet jauh. Penelitian ini bersifat kuantitatif, dengan pendekatan cross sectional. Hasil penelitian, smartphone saat standby tertinggi Blackberry, terendah Samsung. Saat panggilan tertinggi Blackberry dan Nokia, terendah Samsung. Saat menerima panggilan, terbesar adalah Blackberry, terendah Samsung. Berdasarkan hasil uji ANOVA terdapat perbedaan bermakna $(\mathrm{p}=0,003 ; \mathrm{p}<0,05)$ induksi elektromagnetik pada keempat merk smartphone saat melakukan panggilan. Sedangkan pada saat standby dan menerima panggilan tidak terdapat perbedaan yang bermakna $(\mathrm{p}=0,120$ dan $\mathrm{p}=0,115 ; \mathrm{p}>0,05)$. Oleh karena tidak terdapat perbedaan secara statistik maka diperlukan analisis lanjutan (post-hoc) dengan melakukan uji Beda Nyata Terkecil (BNT) atau Least Significance Diferrence (LSD). Terdapat perbedaan yang bermakna atas induksi elektromagnetik smartphone antara merk Samsung, Nokia, dan Blackberry pada saat melakukan panggilan. Sedangkan dari keempat merk smartphone tersebut ternyata perbedaan induksi elektromagnetik antara merk Samsung dan Nokia memiliki perbedaan yang paling signifikan $(\mathrm{p}=0,001)$ kemudian diikuti oleh perbedaan antara merk Samsung dengan Blackberry $(p=0,002)$. Hal ini dapat juga kita lihat pada selisih perbedaan rerata dari keempat merk tersebut dimana selisih rerata induksi elektromagnetik 
antara merk Samsung dengan Nokia merupakan yang terkecil $(-4,035)$ kemudian diikuti oleh selisih antara merk Samsung dengan Blackberry $(-4,001)$.

Kata kunci: Handphone, induksi elektromagnetik, lapangan radiasi.

Radiasi merupakan hal yang ditakuti dalam kehidupan manusia, karena membahayakan dan mengganggu kesehatan serta keselamatan. Namun, tanpa disadari dalam kehidupan seharihari kita sering terpapar radiasi. Radiasi merupakan perambatan energi dari sumber energi ke lingkungannya tanpa membutuhkan panas, misalnya perambatan panas, cahaya dan induksi radio. Terdapat radiasi induksi dengan spektrum frekuensi yang kecil dengan spektrum gelombang yang cukup lebar. Contoh induksi elektromagnetik adalah gelombang radio, sinyal televisi, sinar radar, cahaya tak terlihat, sinar-x dan sinar gamma. Dalam ruang hampa, gelombang ini semuanya merambat dengan kecepatan yang sama, $3 \times 10^{8} \mathrm{~m} / \mathrm{s}$. Sumber elektromagnetik ada dimana-mana, antara lain, matahari, bintang, dan tornado merupakan sumber alamiah dari induksi elektromagnetik. Ada juga sumber elektromagnetik buatan seperti ledakan nuklir, rangkaian listrik dengan tube vakum atau transistor, diode microwave, laser, antena radio serta handpone selular. $^{1-5}$

Telpon seluler atau lebih dikenal sebagai handphone, telah menjadi kebutuhan primer bagi masyarakat, dan seakan tidak pernah terpisahkan dari kehidupan masusia. Handphone merupakan sumber radiasi potensial yang membahayakan kadang tidak disadari oleh penggunanya. Badan Kesehatan Dunia (WHO) pernah meneliti bahwa tidak ada peningkatan resiko kanker pada pengguna ponsel. Namun bukti-bukti baru membuat WHO mengumumkan bahwa radiasi ponsel tidak boleh diabaikan karena bisa sebabkan kanker otak. Tapi dalam pengumumannya kali ini, WHO mengatakan tidak bisa mengesampingkan resiko itu karena sudah ada sedikit penelitian mengenai pengaruh jangka panjang penggunaan telepon seluler., 1,2,6,7

Hasil penelitian terbaru mengungkapkan radiasi ponsel dapat menyebabkan resiko kanker otak serta infertilitas. Radiasi ponsel dikategorikan sama dengan zat karsinogenik berbahaya seperti timbal, asap knalpot, dan kloroform. Hal tersebut diumumkan oleh organisasi kesehatan dunia, World Health Organization (WHO), seperti dikutip dari CNN dan BBC. ${ }^{8,9}$

Telepon seluler pada dasarnya adalah radio yang mengirimkan signal dalam bentuk gelombang ke stasiun. Signal yang dikirim membentuk dua buah lapangan radiasi yakni, medan magnet dekat dan medan magnet jauh. Organisme hidup, juga menghasilkan medan elektromagnetik di, jaringan, organ, dan organisme tingkat sel, yang disebut biofield. Kedua medan magnet dari telepon seluler dapat merusak medan magnet biofield pada tubuh manusia sehingga akan mempengaruhi metabolisme dan fisiologi tubuh. ${ }^{3,10}$

Gelombang pada sebagian besar telepon seluler pada kisaran 1900 megahertz $(\mathrm{MHz})$, yang sebagian besar tidak terlihat oleh jaringan biologis manusia dan tidak menyebabkan kerusakan. Masalah mulai terjadi waktu informasi yang membawa data sekunder, di interpretasikan dalam bentuk suara atau data. Siklus gelombang dalam hertz $(\mathrm{Hz})$ kisarannya akrab bagi tubuh. Misalnya, Jantung berberdetak pada dua siklus per detik, atau dua Hz. Tubuh kita mengenali gelombang pembawa informasi sebagai 
"penginvasi," terjadi reaksi di tempat pelindung biokimia yang kemudian merubah bentuk fisiologis tubuh dan yang menyebabkan masalah biologis yang mencakup penumpukan radikal bebas intraseluler, kebocoran dalam sawar darah-otak, kerusakan genetik, gangguan komunikasi antar sel, dan peningkatan risiko tumor. Bahaya kesehatan dari sinyal, oleh karena tidak menyebabkan kerusakan langsung, melainkan memicu respon biokimia dalam sel., ${ }^{3,11}$ Berdasarkan fakta-fakta tersebut, penulis tertarik untuk meneliti gambaran elektromagnetik beberapa jenis handphone yang biasa digunakan oleh mahasiswa kedokteran Unsrat.

\section{METODOLOGI PENELITIAN}

Penelitian bersifat kuantitatif, dengan pendekatan cross sectional. Dengan menggunakan handphone/smartphone mahasiswa kedokteran Universitas Sam Ratulangi angkatan 2013 dengan merek Blacberry, Nokia, Apple dan Samsung.

\section{HASIL PENELITIAN DAN PEMBAHASAN}

Dari hasil penelitian diperoleh: smartphone yang memiliki induksi elektromagnetik 16-20 mG pada keadaan standby sebagian besar terdapat pada merk Blackberry yakni 2 buah (18,2\%), sedangkan untuk smartphone yang memiliki induksi elektromagnetik 0-5 mG pada keadaan standby sebagian besar terdapat pada merk Samsung yakni sebanyak 11 buah (91,7\%) (Tabel 1).

Handphone yang memiliki induksi elektromagnetik 11-15 mG pada saat melakukan panggilan sebagian besar terdapat pada merk Blackberry dan Nokia yakni masing-masing 1 buah, sedangkan untuk smartphone yang memiliki induksi elektromagnetik 0-5 mG pada saat melakukan panggilan sebagian besar terdapat pada merk Samsung yakni sebanyak 12 buah (100\%) (Tabel 2).

Handphone yang memiliki induksi elektromagnetik 16-20 mG pada saat menerima panggilan sebagian besar terdapat pada merk Blackberry yakni 2 buah (18,2\%), sedangkan untuk handphone yang memiliki induksi elektromagnetik 0-5 mG pada saat melakukan panggilan sebagian besar terdapat pada merk Samsung yakni sebanyak 9 buah (75,0\%) (Tabel 3).

Berdasarkan hasil uji ANOVA maka ditemukan bahwa terdapat perbedaan bermakna ( $\mathrm{p}=0,003 ; \mathrm{p}<0,05)$ induksi elektromagnetik pada keempat merk handphone saat melakukan panggilan. Sedangkan pada saat standby dan menerima panggilan tidak terdapat perbedaan yang bermakna induksi elektromagnetik keempat handphone tersebut $(\mathrm{p}=0,120$ dan $\mathrm{p}=0,115 ; \mathrm{p}>$ 0,05). Oleh karena secara statistik terdapat perbedaan induksi elektromagnetik keempat handphone pada saat melakukan panggilan maka 3 selanjutnya diperlukan analisis lanjutan (post-hoc) dengan melakukan uji Beda Nyata Terkecil (BNT) atau Least Significance Diferrence (LSD) untuk mengetahui perbedaan pada masingmasing dari keempat merk handphone tersebut (Tabel 4).

Terdapat perbedaan yang bermakna atas induksi elektromagnetik handphone antara merk Samsung, Nokia, dan Blackberry pada saat melakukan panggilan. Sedangkan dari keempat merk handphone tersebut ternyata perbedaan induksi elektromagnetik antara merk Samsung dan Nokia memiliki perbedaan yang paling signifikan $(\mathrm{p}=0,001)$ kemudian diikuti oleh perbedaan antara merk Samsung dengan Blackberry $(\mathrm{p}=$ 0,002). Hal ini dapat juga kita lihat pada selisih perbedaan rerata dari keempat 
merk tersebut dimana selisih rerata induksi elektromagnetik antara merk Samsung dengan Nokia merupakan yang terkecil $(-4,035)$ kemudian diikuti oleh selisih antara merk Samsung dengan Blackberry $(-4,001)$ (Tabel 5).

Tabel 1. Sebaran data induksi elektromagnetik handphone pada saat standby.

\begin{tabular}{lcccccccc}
\hline \multirow{2}{*}{ Merk } & \multicolumn{2}{c}{$0-5 \mathrm{mG}$} & \multicolumn{2}{c}{$6-10 \mathrm{mG}$} & \multicolumn{2}{c}{$16-20 \mathrm{mG}$} & \multicolumn{2}{c}{ Total } \\
\cline { 2 - 9 } & $\mathrm{n}$ & $\%$ & $\mathrm{n}$ & $\%$ & $\mathrm{~N}$ & $\%$ & $\mathrm{~N}$ & $\%$ \\
\hline Samsung & 11 & $91.7 \%$ & 1 & $8.3 \%$ & 0 & $0.0 \%$ & 12 & $100 \%$ \\
Nokia & 8 & $66.7 \%$ & 4 & $33.3 \%$ & 0 & $0.0 \%$ & 12 & $100 \%$ \\
Blackberry & 8 & $72.7 \%$ & 1 & $9.1 \%$ & 2 & $18.2 \%$ & 11 & $100 \%$ \\
Apple & 3 & $100.0 \%$ & 0 & $0.0 \%$ & 0 & $0.0 \%$ & 3 & $100 \%$ \\
\hline
\end{tabular}

Tabel 2. Sebaran data induksi elektromagnetik handphone pada saat melakukan panggilan

\begin{tabular}{lcccccccc}
\hline \multirow{2}{*}{ Merk } & \multicolumn{2}{c}{$0-5 \mathrm{mG}$} & \multicolumn{2}{c}{$6-10 \mathrm{mG}$} & \multicolumn{2}{c}{$11-15 \mathrm{mG}$} & \multicolumn{2}{c}{ Total } \\
\cline { 2 - 9 } & $\mathrm{n}$ & $\%$ & $\mathrm{~N}$ & $\%$ & $\mathrm{~N}$ & $\%$ & $\mathrm{n}$ & $\%$ \\
\hline Samsung & 12 & $100.0 \%$ & 0 & $0.0 \%$ & 0 & $0.0 \%$ & 12 & $100 \%$ \\
Nokia & 4 & $33.3 \%$ & 7 & $58.3 \%$ & 1 & $8.3 \%$ & 12 & $100 \%$ \\
Blackberry & 5 & $45.5 \%$ & 5 & $45.5 \%$ & 1 & $9.1 \%$ & 11 & $100 \%$ \\
Apple & 2 & $66.7 \%$ & 1 & $33.3 \%$ & 0 & $0.0 \%$ & 3 & $100 \%$ \\
\hline
\end{tabular}

Tabel 3. Sebaran data induksi elektromagnetik handphone pada saat menerima panggilan

\begin{tabular}{|c|c|c|c|c|c|c|c|c|c|c|}
\hline \multirow{2}{*}{ Merk } & \multicolumn{2}{|c|}{$0-5 \mathrm{mG}$} & \multicolumn{2}{|c|}{ 6-10 mG } & \multicolumn{2}{|c|}{$11-15 \mathrm{mG}$} & \multicolumn{2}{|c|}{$16-20 \mathrm{mG}$} & \multicolumn{2}{|c|}{ Total } \\
\hline & $\mathrm{n}$ & $\%$ & $\mathrm{~N}$ & $\%$ & $\mathrm{~N}$ & $\%$ & $\mathrm{~N}$ & $\%$ & $\mathrm{~N}$ & $\%$ \\
\hline Samsung & 9 & $75.0 \%$ & 3 & $25.0^{\circ}$ & 1 & $0.0 \%$ & 0 & $0.0 \%$ & 12 & $100 \%$ \\
\hline Nokia & 5 & $41.7 \%$ & 5 & $41.7^{\circ}$ & & $8.3 \%$ & 1 & $8.3 \%$ & 12 & $100 \%$ \\
\hline Blackberry & 3 & $27.3 \%$ & 5 & $45.5 \%$ & 1 & $9.1 \%$ & 2 & $18.2 \%$ & 11 & $100 \%$ \\
\hline Apple & 2 & $66.7 \%$ & 0 & $0.0 \%$ & 1 & $33.3 \%$ & 0 & $0.0 \%$ & 3 & $100 \%$ \\
\hline
\end{tabular}

Tabel 4. Hasil Analisis Statistik (Analisis Varians/ ANOVA) tingkat perbedaan induksi elektromagnetik pada keempat merk handphone

\begin{tabular}{lcc}
\hline \multicolumn{1}{c}{ Status Smartphone } & A & P \\
\hline Standby & & 0,120 \\
Melakukan panggilan & 0,05 & 0,003 \\
Menerima panggilan & & 0,115
\end{tabular}

Tabel 8. Hasil analisis post-hoc Least Significance Difference tingkat perbedaan induksi elektromagnetik pada saat panggilan keluar dari keempat merk handphone 


\begin{tabular}{clccc}
\hline & Merk & Beda Rataan & A & P \\
\hline Samsung & Nokia & $-4.03500^{*}$ & & 0.001 \\
& Blackberry & $-4.00129^{*}$ & 0,05 & 0.002 \\
& Apple & -1.13917 & & 0.537 \\
\hline Nokia & Samsung & $4.03500^{*}$ & & 0.001 \\
& Blackberry & 0.03371 & 0,05 & 0.977 \\
& Apple & 2.89583 & & 0.122 \\
\hline Blackberry & Samsung & $4.00129^{*}$ & & 0.002 \\
& Nokia & -0.03371 & 0,05 & 0.977 \\
& Apple & 2.86212 & & 0.130 \\
\hline Apple & Samsung & 1.13917 & & 0.537 \\
& Nokia & -2.89583 & 0,05 & 0.122 \\
& Blackberry & -2.86212 & & 0.130 \\
\hline
\end{tabular}

Berdasarkan tabel diatas ditemukan bahwa terdapat perbedaan yang bermakna atas induksi elektromagnetik handphone antara merk Samsung, Nokia, dan Blackberry pada saat melakukan panggilan. Sedangkan dari keempat merk handphone tersebut ternyata perbedaan induksi elektromagnetik antara merk Samsung dan Nokia memiliki perbedaan yang paling signifikan $(\mathrm{p}=0,001)$ kemudian diikuti oleh perbedaan antara merk Samsung dengan Blackberry ( $\mathrm{p}=$ 0,002). Hal ini dapat juga kita lihat pada selisih perbedaan rerata dari keempat merk tersebut dimana selisih rerata induksi elektromagnetik antara merk Samsung dengan Nokia merupakan yang terkecil $(-4,035)$ kemudian diikuti oleh selisih antara merk Samsung dengan Blackberry $(-4,001)$.

\section{PENUTUP}

\section{A. Kesimpulan}

Dari hasil penelitian panjang induksi elektromagnetik handphone yang biasa digunakan oleh mahasiswa kedokteran Universitas Sam Ratulangi angkatan 2013, dapat ditarik kesimpulan bahwa:

1. Saat Standbye, melakukan panggilan, dan menerima panggilan, handphone yang memiliki induksi elektromagnetik dari yang terbesar sampai terkecil, berturut-turut adalah Blackberry, Nokia, Apple dan terkecil Samsung.

2. Hasil uji ANOVA ditemukan terdapat perbedaan bermakna ( $\mathrm{p}=0,003$; $\mathrm{p}<0,05)$ induksi elektromagnetik pada keempat merk Handphone saat melakukan panggilan.

3. Hasil analisis post-hoc Least Significance Difference terdapat perbedaan yang bermakna atas induksi elektromagnetik smartphone antara merk Samsung, Nokia, dan Blackberry pada saat melakukan panggilan.

\section{B. Saran}

1. Perlu penelitian secara berkala untuk merek-merek handphone lain yang 
bukan original produk yang ternyata banyak digunakan saat ini oleh masyarakat.

2. Perlu dipertimbangkan untuk memasang anti radiasi untuk mengurangi efek radiasi elektromagmetik dari handphone terhadap kesehatan.

\section{REFERENSI}

1. United States General Accounting Office (GAO), Report to Congressional requesters, 2001, "Telecommunications-Research and Regulatory Efforts on Mobile Phone Health Issues”. 2008

2. Medical College of Wisconsin, John Moulder, Professor of Radio Oncology, "Mobile Phone Base Stations and Human Health", avilable at:

http://www.howstuffworks.com/fram ed.htm?parent=cell-phoneradiation.htm\&url=http://www.mcw.e du/gcrc/cop/cell-phonehealth-

3. European Commission, Scientific Committee on Emerging and Newly Identified Health Risks (SCENIHR), "Possible effects of electromagnetic fields (EMF) on human health", March 21, 2007

4. Emami Z., Turan A.G., Razavi S.E. Study of the relationship betwen electromagnetic waves of cell phone and prevalence of the glioma and meningioma. Herald journal of pharmacy and pharmacology. 2012;1(1):1-8

5. Privateline.com, "Digital Wireless Basics: Frequencies. V. Cellular, PCS, GSM, and Japanese Digital Cellular Frequencies”, available at: http://www.privateline.com/PCS/Freq uencies.htm. 2007
6. Adlkofer F., Belyaev I.Y., Richter K., Shiroff V.M. How susceptible are genes to mobile phone radiation?. Effect of wireless comunication technolgi. State of the researchendorsements of safety and controversies - self help recomendations. 2009;3:3-24

7. Howstuffworks.com, "How cellphone radiation works", http://electronics.howstuffworks.com/ cell-phone-radiation.htm/printable. 2007

8. Addiss S.S., Asnes A.G., Alderman N.O., et all. Cell Phones. The cell phone problem. Teknology-exposurehealth issues. Environtment and human health. 2012.

9. WHO. IARC calssifies radiofrequency electromagnetic fields as posibly carcinogenic to humans. Internatioan agency for research on cancer. 2011

10. HowStuffWorks.com, "What is the difference between analog and digital cell phones?”,http://www.howstuffworks. com/question31.htm/printable (Accessed June 27, 2007)

11. CWA, "Microwave \& Radio Frequency Radiation”, http://www.cwaunion.org/issues/osh/articles/page.jsp ?itemID=27339127

12. Mannix. Cell phone safety factsheet. Radiation safety division. 2011:1-7

13. Kesari K.K., Siddiqui M.H., et all. Cell phone radiation exposure on brain and associated biology system. Indian Journal of experimental biology. 2013;51:187-200

14. Fertility and Sterility, The Official Journal of the American Society for Reproductive Medicine, "Effect of cell phone usage on semen analysis in men attending infertility clinic: an observational study", 
http://www.fertstert.org/article/PIIS0

015028207003329/ Accessed May 2013

15. Boriraksantikul1 B., Bhattacharyya N., Boriraksantikul C., et all. case study of high blood glucose concentration effects of $850 \mathrm{mhz}$ electromagnetic fields using gtem cell. Progress In Electromagnetics Research B. 2012;40:55-77

16. Elachi C, Jakob van Zyl. Introduction to the Physics and Techniques of Remote Sensing, John Wiley \& Sons, New Jersey.2008

17. Mather, P.M. Computer Processing of Remotely-Sensed Images, Third Edition, John Wiley \& Sons, New Jersey. 2008

18. Schowengerdt, R.A. Remote Sensing: Models and Methods for Image Processing, Third Edition, Elsevier Inc. California. 2009.

19. Wargo J, Taylor HS, Alderman N, Wargo L, Bradley JM, Addis S. Cell Phone. The cell phone problem. Technology-Exposure-health effect. 2012;3-64.

20. Glodsworthy A. The Biological Effects of Weak Electromagnetic Fields Problems and solutions. 2012:1-24.

21. Carlo G. The hidden dangers of cell phone radiation. LE magazine. Sue Kovach. 2001

22. Bhargavi K., Balachandrudu K.E., Nageswar P. Mobile Phone Radiation Effects on Human Health. Int carernational Journal of Computational Engineering Research. 2013;3(4):196-203)

23. Mahajan A., singh M. Human health and electromagnetic radiations. International Journal of Engineering and Innovative Technology (IJEIT). 2012;1(6):95-7
24. Mercola. Cell phone radiation, is the danger all in your head? Mercola.com. 2012. 